\title{
Human Capital, Productivity and Economic Growth in 31 Sub-Saharan African Countries for the Period 1975-2008
}

\author{
Girma Zelleke ${ }^{1}$, Abdulwahab Sraiheen ${ }^{1} \&$ Keshav Gupta ${ }^{1}$ \\ ${ }^{1}$ College of Business, Kutztown University of Pennsylvania, Kutztown, USA \\ Correspondence: Girma Zelleke, College of Business, Kutztown University of Pennsylvania, Kutztown, PA \\ 19530, USA. Tel: 1-610-683-4598. E-mail: zelleke@kutztown.edu
}

Received: June 21, 2013

Accepted: August 20, 2013 Online Published: September 26, 2013

doi:10.5539/ijef.v5n10p1

URL: http://dx.doi.org/10.5539/ijef.v5n10p1

\begin{abstract}
We evaluate the contributions of physical capital, human capital, and unskilled labor to economic growth for 31 Sub-Saharan African (SSA) countries. We find that growth in physical capital accounts for 67 percent of growth in real GDP, whereas growth in human capital accounts for only 22 percent of real GDP growth and, the rest 11 percent is accounted for by growth of raw labor. When it comes to growth of productivity per employed worker, 90 percent is accounted for by growth rate of physical capital per employed worker, 46 percent by rate of increase in human capital per worker and negative 36 percent by rate of change of total factor of productivity (TFP). These findings are consistent with earlier studies. Negative contribution of growth rate in TFP may have to do with, poor governance, corruption, civil wars, draught and other adverse supply shocks to the production function. In addition, we find that the contributions of labor and human capital are positive but much lower in SSA countries than in high-income countries.
\end{abstract}

Keywords: Africa, human capital, economic growth, growth accounting, productivity

\section{Introduction}

Zelleke and Sraiheen (2012) use growth accounting approach to identify the sources of economic growth in a sample of SSA countries. This study extends their study to evaluate the contributions of human capital, in addition to physical capital and unskilled labor, to economic growth and productivity increase in 31 SSA countries (Note 1) for the 1975-2008 time period. We use Pritchett (2001) and Weil (2013) conceptual frameworks to estimate the income share of human capital.

Inclusion of human capital, in addition to physical capital and raw labor, as a determinant of economic growth in Solow's growth theory (Solow, 1956) was first introduced by Mankiw, Romer, and Weil (1992). With inclusion of human capital as one of the determinants of economic growth Mankiw et al. managed to overcome the specification bias that resulted from omission of human capital in their first empirical estimate of Solow's growth model. However, the proxy variable used in their measurement of human capital is imprecise. It is obtained by multiplying the fraction of school age population (12-17 years old) that is enrolled in secondary education, by the fraction of the school age population 15-19 years of age in the labor force. By including human capital as an explanatory variable, Mankiw et al. conclude that 80 percent of the variation in standard of living across countries is explained by human capital augmented version of the Solow growth model.

Pritchett (2001) arrives at an entirely different conclusion about the role and impact of human capital. Using cross sectional data, he finds that growth rate of human capital has a negative but statistically insignificant coefficient on growth rate of output (GDP). According to Pritchett, human capital may increase the private rate of return to those who have acquired human capital but this return is a consequence of their engagement in rent-seeking behavior and not from a productive activity that would increase GDP. If Pritchett's assertion were true one would expect to see the growth rate of GDP in industrialized countries, where the income share of human capital is high, to be lower than in low-income countries. In spite of Pritchett's conjecture that education may be the mother of all corruption and rent seeking behavior, the methodology employed in his study to measure the human capital share of total wage income is a significant improvement over the method used by Mankiw et al. (1992). Pritchett's methodology is recently expounded by Weil (2013) and appears to be a standard tool for measuring the contributions of human capital to economic growth and productivity in empirical studies of the Solow's human capital augmented growth model or the Cobb-Douglas growth model. 
Although both theories predict a substantial portion of the underlying causes of economic growth and development, a statistical test that is grounded on cross sectional data collected from various countries is likely to encounter a specification bias. This specification bias may arise from omission of relevant variables that are as important as the variables included in Solow's or the neoclassical growth models. Such variables may include cross country variations in economic systems, public or private ownership of assets, openness to international trade, transparency and democratization of governance structures and many others that are hard to quantify in any objective manner. It is possible that the unexpected negative association between economic growth and human capital that is reported in Pritchett (2001) study could be due to such a specification bias.

Bosworth and Collins (2003) avoid the cross country variation bias by restricting the sample data to a group of countries where variations of governance systems, degree of openness to international trade and public versus private ownership of assets are minimal. Using 10 years of panel data for the period $1960-2000$, Bosworth and Collins estimate the sources of growth for seven different regions (Industrialized countries, China, East Asia except China, South Asia, Latin America, Africa and the Middle East).

The most significant difference between the current study and all other previous studies is that we do not make the assumption that the national income share of labor and capital in low-income countries, such as SSA countries, is the same as that in high-income industrialized countries. In all the previous studies, that we are aware of, the income share of capital is assumed to be at 33 percent and that of labor at 67 percent of GDP. In low-income countries, with elastic supply of labor relative to demand for labor, the wage rate and income share of employed workers is likely to be much less than in high income countries. Instead of relying on hypothetical assumptions of a uniform income share coefficients of labor and capital, we make a statistical estimate of capital and labor's share of national income for Kenya and for South Africa from recent data reported in Extended Penn World Tables v. 4.0 (EPWT 4.0) (Marquetti \& Foley, 2012). We find that for South Africa, a relatively developed country, factor income share coefficients are close to income share coefficients of industrialized countries but for Kenya the share of labor income is much lower. As Kenya's standard of living and economic structure is similar to the rest of the SSA countries, we have applied the income share coefficients obtained from Kenya's data to estimate the contributions of factor growth to growth rate of GDP and to productivity.

\section{Theoretical Model}

We start with the human-capital augmented version of Cobb-Douglas (CD) production function. With human capital included, the $\mathrm{CD}$ model is specified as,

$$
Y=A\left(K^{\alpha} H^{\beta} L^{\lambda}\right)
$$

Where $(\mathrm{Y})$ is real GDP, $(\mathrm{K})$ is physical capital stock net of depreciation, $(\mathrm{H})$ is human capital measured by formal education embodied in labor, and (L) is raw labor with zero education. The exponents in equation (1) are measures of income shares of physical capital $(\alpha)$, wage share of human capital embodied in labor $(\beta)$ and $(\lambda)$ is the wage share paid to raw labor with zero education. The income share coefficients $(\alpha, \beta$ and $\lambda)$ are the same as elasticity of output with respect to each of the respective factor inputs. Assuming perfect competition and constant returns to scale, we have $(\alpha+\beta+\lambda=1)$. Equation (1) can then be specified as,

$$
\mathrm{Y}=\mathrm{A}\left(K^{\alpha} H^{\beta} L^{1-\alpha-\beta}\right)
$$

Taking natural log of both sides we have equation (3) with $(\mathrm{Ln})$ denoting the natural log of the variables,

$$
\operatorname{Ln}(Y)=\operatorname{Ln}(A)+\alpha \operatorname{Ln}(K)+\beta \operatorname{Ln}(H)+\lambda \operatorname{Ln}(L)
$$

To estimate the factor share coefficients of equation 3, we employ maximum likelihood (ML) method with real GDP (Y) as a dependent variable and, all other variables on the right side of the equation as independent variables. The method we employ to disaggregate total wage income, between wage share of human capital and, wage share of raw labor, draws upon the methodological approach developed by Pritchett (2001) and expounded by Weil (2013). Details of this methodology are discussed in section 3.

Dividing the left and right side of equation ( 2 or 3 ) by the total number of employed workers (L) and rearranging the terms yields,

$$
y=A k^{\alpha} h^{\beta}
$$

Where the superscripts $\alpha$ and $\beta$ are measures of contributions of physical and human capital to productivity of each employed worker. Equation (4) states that productivity per employed worker $\left(y=\frac{\eta}{L}\right)$ is a positive function 
of physical capital per employed worker $\left(k=\frac{K}{L}\right)$, human capital per employed worker $\left(h=\frac{H}{L}\right)$ and factor neutral state of technology (A).

To estimate equation (4) we take natural log of both sides to obtain the following equation,

$$
\operatorname{Ln}(y)=\operatorname{Ln}(A)+\alpha \operatorname{Ln}(k)+\beta \operatorname{Ln}(h)
$$

Equation (5) can then be estimated using ML method.

The estimated coefficients of $(\alpha, \beta$ and $\lambda)$ from equation (3) are substituted in equations ( 1 or 2$)$ to obtain the predicted value of real GDP $(\hat{Y})$. The value of (A) is then obtained by dividing the actual value of real GDP (Y) by its predicted value $(\hat{Y})$,

$$
A=\frac{Y}{\hat{Y}}=\frac{Y}{\left(K^{\widehat{\alpha}} H^{\widehat{\beta}} L^{1-\widehat{\alpha}-\widehat{\beta}}\right)}
$$

This (A) is commonly referred to as Solow's Residual or Total Factor Productivity (TFP),

The time derivative of equations ( 1 or 2) yields (Note 2),

$$
\dot{Y}=\dot{a}+\alpha \dot{K}+\beta \dot{H}+\lambda \dot{L}
$$

The growth accounting equation (6) identifies the sources of GDP growth $\left[\dot{Y}=\operatorname{Ln}\left(\frac{Y_{t}}{Y_{t-1}}\right)\right]$ as consisting of the growth rates of the three factor inputs, physical capital $\left[\dot{K}=\operatorname{Ln}\left(\frac{K_{t}}{K_{t-1}}\right)\right]$, human capital $\left[\dot{H}=\operatorname{Ln}\left(\frac{H_{t}}{H_{t-1}}\right)\right]$ and raw labor $\left[\dot{L}=\operatorname{Ln}\left(\frac{Y_{t}}{Y_{t-1}}\right)\right]$ plus factor neutral growth of technical change $\left[\dot{a}=\operatorname{Ln}\left(\frac{A_{t}}{A_{t-1}}\right)\right]$. Although TFP in growth literature is assumed to capture the influence of only factor neutral technical change, in reality it also reflects country and time specific exogenous variations of GDP growth. Similarly, the time derivative of equation (4) yields the following equation (Note 3),

$$
\dot{y}=\dot{a}+\alpha \dot{k}+\beta \dot{h}
$$

This equation shows that the growth rate of productivity $\left[\dot{y}=\operatorname{Ln}\left(\frac{y_{t}}{y_{t-1}}\right)\right]$ per employed worker is determined by growth rates of physical capital per employed worker $\left[\dot{k}=\operatorname{Ln}\left(\frac{k_{t}}{k_{t-1}}\right)\right]$, human capital per employed worker $\left[\dot{h}=\operatorname{Ln}\left(\frac{h_{t}}{h_{t-1}}\right)\right]$ and by growth rate of TFP $\left[\dot{a}=\operatorname{Ln}\left(\frac{A_{t}}{A_{t-1}}\right)\right]$ (Abel, Bernanke \& Croushore, 2008).

In essence equation (7) is a human capital augmented version of the Solow growth model without an explicit specification of the steady state of output per worker that makes use of stock adjustment model (Jorgensen, 1967). In equations (6) and (7) the term $(\dot{a})$ represents the growth rate of TFP and may include exogenous factors such as, changes in technology, negative or positive shocks that can affect the level and growth rate of output, the extent of political corruption, drought, the presence or absence of protracted civil wars, changes in the terms of trade and time-specific changes in institutional arrangements and governance structures. Most of these exogenous variables are hard to quantify in any meaningful way.

\section{Measurement of Human Capital}

To estimate the income share coefficients of physical capital $(\alpha)$, human capital $(\beta)$ and raw labor $(\lambda)$, as specified in equations $(2 \& 3)$, we generate a time series data for the period 1975-2008. Our time series data disaggregates the total wage income of workers between the fraction of wage income attributable to human capital and the fraction attributable to raw labor, using Barro-Lee educational attainment dataset (Barro \& Lee, 2012). Although the term human capital in growth literature is a broadly defined term that encompasses workers attributes such as, health status, work experience and innate abilities, our definition of the term "human capital" is restricted to only formal educational attainment.

The approach we use to measure human capital is based on the methodology developed by Pritchett (2001) and expounded by Weil (2013). Investment in education, like any other investment in physical capital, will yield a return that can be computed by making use of the rate of return formula,

$$
R_{i}=R_{i-1}\left(1+r_{i}\right)^{E_{i}-E_{i-1}} \quad i=1,2,3
$$

Where $\left(R_{i}\right)$ is total return to an educated worker from investment in education and from raw labor, $\left(r_{i}\right)$ is the rate 
of return for each year of schooling and $\left(E_{i}\right)$ the number of years of schooling attained by educational attainment group (i). We then calculate the wage share of human capital as follows;

$$
\text { Wage Share of Human Capital }(S H)=\frac{\sum \theta_{i} R_{i}-R_{0}}{\sum \theta_{i} R_{i}} \times W_{S}
$$

Where $\left(\theta_{i}\right)$, is the proportion of population in educational attainment category (i), $R_{\mathrm{o}}$ is the wage rate of a worker with no education and $W_{S}$ is the total wage share of all workers including those with and without human capital embodied in their labor.

The return from schooling is calculated by using a compounding rate of 16 percent for each year of primary education (grades 1-6), 10 percent for each year of secondary education (grades 7-12) and 8 percent for each year of tertiary education. The compounding rates we use to estimate the rate of return from investment in human capital are average rates of return values estimated for a cross section of developing countries based on Mincerian (Mincer, 1974) equation for determination of wage rates (Psacharopoulos, 1994). The decline in the rate of return from investment in secondary and tertiary education compared to primary education is based on the assumption that the opportunity cost of attending schools, which comprises of forgone earnings, is less for primary school students than it is for secondary or tertiary level students.

To better understand the procedure we use to measure the return from investment in human capital, consider a hypothetical country that has four distinct segments $(0,1,2$ and 3$)$ of its total population with different level of educational attainment. Segment (0) has zero years of schooling and, accounts for say 20 percent of total population, segment (1) has completed six years of primary education and accounts for 30 percent of total population, segment (2) has twelve years of education (secondary education) and accounts for 40 percent of population and segment (3) has sixteen years of education (tertiary education) and accounts for 10 percent of population. If a worker with zero education earns $\$ 1$, a worker with six years of primary education in segment (1) will earn $\$ 1 \times(1.16)^{6}=\$ 2.44$, a worker with 12 years of education will earn $\$ 2.44 \times(1.10)^{6}=\$ 4.32$. Similarly, a person with 16 years education will earn $\$ 4.32 \times(1.08)^{4}=\$ 5.87$. If we multiply the earnings of each segment of population by the population share of the respective segment, we can obtain the average earning received by all four segments as $\{(0.2 \times \$ 1)+(0.3 \times \$ 2.44)+(0.40 \times \$ 4.32)+(0.1 \times \$ 5.87)\}=\$ 3.25$. Here $\$ 3.25$ represents the average wage earning of four segments of population. The excess of average wage earned by four segments of (\$3.25) over and above what they could have earned if they had no education $(\$ 1.00)$ must be attributed as a return to human capital or education. In our hypothetical example, the wage share of human capital component of total labor is approximately $0.69\{(3.25-1) / 3.25\}$. Accordingly, the wage share of raw labor component of total labor is $0.31(1-0.69)$.

Using a similar method of computation Weil (2013) reports that for a sample of developing countries the share of human capital as a fraction of total wages is 0.49 . For industrialized countries, where the level of educational attainment is higher, Weil reports the human capital share of total wages to be 0.66 . Multiplying the industrialized countries' human capital share of wage income by their total wage share of GDP of 0.67, Weil obtains the human capital share of GDP of $0.44(0.66 \times 0.67=0.44)$. Similarly for developing countries Weil assumes 0.67 total wage share of GDP, same as in developed countries, and multiplying it by human capital share of total wages he calculates human capital share of GDP as $0.33(0.49 \times 0.67=0.33)$. Weil (2013) does not make an empirical estimate of the income shares of capital and labor for developing countries. Instead, he assumes that the income share of capital owners and labor in developing countries is the same as it is in developed countries.

Having assumed the share of physical capital as 33 percent of GDP for developing countries, same as that for developed countries, and on that basis having calculated share of human capital as 33 percent of GDP, Weil (2013) goes on to assert that:

This rising importance of human capital is what actually drove the decline of class politics in much of the world. When workers and capitalists are one and the same, the idea of class struggle makes less sense. In other words, throughout the world, workers are in effect "capitalists" in the sense that they are earning a return to their own earlier investments in human capital of 33 percent which is the return to physical capital of 33 percent. (pp. 167168).

Such a conclusion is indeed music to the ear of any peace-loving person. Weil's analysis (Weil, 2013) and conclusions draw upon an earlier work by Galor and Moav (2006), who explain why capital owners during the early $20^{\text {th }}$ century supported the Balfour Act of 1902 in England. The goal of the Balfour Act was to provide free public education for the masses as a strategy to reverse the declining trend of profit that resulted from an increase 
in capital to labor ratio. The provision of public education, which was initially financed by capital owners, helped to create human capital as a complementary resource of physical capital to reverse the declining rate of profit. The complementary use of human and physical capital increased output per worker and the wage rate of labor enabling workers to save and invest more on physical as well as human capital of their children as implied by endogenous theory of economic growth. The rise of wage income from investment in public education transformed workers to become capitalists thereby averting the potential conflict between workers and capitalists as was predicted by Marxian analysis.

Weil's conclusion (Weil, 2013) could be valid for industrialized high-income countries where labor's share of income is as high as 67 percent and physical capital owner's share of income is 33 percent of GDP. However, in most SSA countries the majority of the labor force is engaged in the informal urban sector or in subsistence agriculture with little or no physical capital. We show that for such countries the wage share of GDP is very low and much less than 67 percent and Weil's assertion may not be valid.

Perry (2012), a journalist familiar with political and economic developments in Nairobi, Kenya, reports as follows:

Nairobi encapsulates Africa's transformation. From vendors at traffic light selling iPad chargers to millions of neatly suited commuters, signs of change are everywhere.

Africa owes its takeoff to foreign-debt cancellations; a concurrent interest in Africa's natural resources, led by China; and a rapid spread of mobile phones.

While these phenomena combine in a tsunami of change at a continental level, their local impact can be uneven, and Nairobi is a prime example. Pass through the city center at noon and you'll find daily protests by striking doctors, teachers and university lecturers, all demanding increases in what are, in some cases, risible wages. (p. $50)$.

Perry's depiction of realities in Nairobi (Perry, 2012) seems to be in conflict with Weil's optimism that labor's share of income in developing countries is high and that the return on human capital is also as high as the return to physical capital (Weil, 2013). In view of these conflicting reports, we empirically examine whether or not Weil's conclusion is valid for Kenya and other SSA countries. At least in SSA countries most of the investment in human capital does not appear to have yielded a high rate of return as evidenced by high rate of unemployment among the educated youth. This may be partly due to limited complementarity between labor and capital intensive industries in the oil and mining sector. According to Perry's report nearly half of university graduates leave countries like Kenya and Ghana. Although the street protests by teachers, university professors and medical doctors for a wage increase could be directed against corrupt politicians, whose primary goal is to advance their self-interest at the expense of their fellow citizens, it remains a fact that the private rate of return from investment in human capital in most SSA countries is low.

\section{Sources of Data and Samples}

Our study includes 31 SSA countries with data for each country covering the period from 1975-2008 except for Liberia and Swaziland. For the latter countries, the data used is for the period 1985-2008. Data on wage share of real GDP, number of employed workers (hereinafter also referred to as labor), physical capital stock net of depreciation and real GDP are taken from the EPWT 4.0 (Marquetti \& Foley, 2012). Data on educational attainment are from Barro-Lee Educational Attainment Dataset (Barro \& Lee, 2012).

A complete set of data on wage share of real GDP for the period 1975-2008 is reported in EPWT 4.0 (Marquetti \& Foley, 2012) for only Kenya, South Africa and Botswana. For most other SSA countries, wage share data are either unavailable or, the coverage is limited to no more than 10 years.

Among the OECD countries the ratio of wage income to GDP lies within a range of 55-66 percent. As South Africa's per capital income is much higher than in other SSA countries the wage share of GDP for South Africa, at about 55 percent, is close to that for high-income countries. The data as reported in EPWT 4.0 (Marquetti \& Foley, 2012) shows that labor's share of income in low-income SSA countries is much lower than in high-income countries, ranging between $20-40$ percent.

In a previous empirical estimate of the Cobb-Douglas Production function by Bernanke and Gurkaynak (2002), based on a sample of 54 countries, the average share of wage income for all countries in the sample is estimated to be 0.65 . However, among the 54 countries in the sample, the authors report that the estimated coefficients of wage share of income for SSA countries are 0.22 for Burundi, 0.38 for Congo, 0.43 for Ivory Coast, 0.48 for Zambia, 0.39 for Botswana, 0.48 for Mauritius and 0.59 for South Africa. This shows that the average value of the estimated wage share coefficients for the six low-income SSA countries excluding South Africa is only 0.40, 
which is significantly lower than the average share of wage income of 0.65 reported for all 54 countries.

In contrast to most other previous studies of Growth and Development accounting models (Hall \& Jones, 1999, Mankiw et al., 1992, Pritchett, 2001, Bosworth \& Collins, 2003), whose analysis was based on assumed wage share coefficient of 0.67 and a capital income share coefficient of 0.33 , we use our own statistical estimate of income share coefficients for Kenya and South Africa.

\section{Results of Statistical Estimates}

As described in section (2) the income share coefficients of the three factor inputs (physical capital, human capital and raw labor) are estimated for Kenya and South Africa using data reported for each country in EPWT 4.0 (Marquetti \& Foley, 2012). The results of our estimates are reported in Tables 1 and 2 below.

Table 1. Estimated human capital augmented aggregate production function for Kenya (1974-2008) and South Africa (1969-2008)

\begin{tabular}{ccccc}
\hline Variable & \multicolumn{2}{c}{ Kenya } & \multicolumn{2}{c}{ South Africa } \\
\hline \multirow{2}{*}{ Intercept } & 0.6285 & 0.608 & 4.2683 & 3.8296 \\
& $(2.65)$ & $(2.8)$ & $(3.97)$ & $(3.73)$ \\
$\operatorname{lnK}$ & 0.6422 & 0.6433 & 0.4902 & 0.3979 \\
& $(97.59)$ & $(96.03)$ & $(6.48)$ & $(4.74)$ \\
$\ln \mathrm{TL}$ & 0.3695 & & 0.5407 & \\
& $(70.13)$ & & $(6.12)$ & \\
$\ln \mathrm{H}$ & & 0.1495 & & 0.2244 \\
& & $(13.07)$ & & $(2.05)$ \\
$\operatorname{lnRL}$ & & 0.221 & & 0.3749 \\
$\mathrm{R}^{2}$ & 1 & $(15.78)$ & & $(3.21)$ \\
$\mathrm{n}$ & 39 & 1 & 0.9971 & 0.9994 \\
\hline
\end{tabular}

T-statistics in parentheses. AR2 maximum likelihood method. LnK: Natural Log of Physical Capital; LnTL: Natural Log of Total Labor; LnH: Natural Log of Human Capital; LnRL: Natural Log of Raw Labor. Dependent variable: Ln (Y): Natural log of real output.

The estimates of income share coefficients $(\alpha, \beta$ and $\lambda$ ) of equation (3) are shown in column 3 for Kenya and in column 5 for South Africa in Table 1. As shown in the table, the elasticity of real GDP coefficients with respect to each of the three factor inputs are $(\alpha=0.6433, \beta=0.1495$ and $\lambda=0.2210)$ for Kenya and $(\alpha=0.3979, \beta=$ 0.2244 and $\lambda=0.3749$ ) for South Africa. All coefficients are estimated using maximum likelihood (ML) method of estimation and are significant at less than 1 percent level of significance. From the estimated coefficients in Table 1, one can observe that the total wage income of workers received from their investment in human capital and from services of raw labor is equal to $0.3705(0.1495+0.2210)$ for Kenya and $0.5993(0.2244+0.3749)$ for South Africa.

The physical capital and labor income share coefficients are reported in column 2 for Kenya and, column 4 for South Africa in Table 1. The output elasticity coefficients with respect to labor are 0.3695 for Kenya but 0.5407 for South Africa. On the other hand, the output elasticity of physical capital is higher for Kenya (0.6422) than it is for South Africa (0.4902). All coefficients for both countries are significant at less than 1 percent level of significance.

These estimates appear to be consistent with previous estimate of labor and physical capital share of output elasticity coefficients estimated by Bernanke and Gurkaynak (2002) for South Africa and for six other low-income SSA countries for 1960-1995 time period. In their study labor's share of income is reported to be 0.59 for South Africa and an average value of 0.40 for six low-income SSA countries included in their sample of 54 mostly OECD countries.

It is instructive to note that the total wage share of GDP which consists of the return from human capital and raw labor is much lower in low-income countries than it is in high-income industrialized countries. As most low-income SSA countries are labor abundant and capital scarce with low capital to labor ratio, the marginal productivity of labor and the wage rate of labor is likely to be very low. In such labor surplus economies, a large portion of the labor force is employed either in rural areas where disguised unemployment is the norm (Lewis, 1955) or in the urban informal sector with a high rate of open unemployment and underemployment due to insufficiency of physical or financial capital. The high rate of unemployment or underemployment of labor and 
low productivity of labor may explain why labor's share of income in low income countries is less than it is in high income countries.

Table 2. Estimated average productivity of physical and human capital per worker for Kenya (1974-2008) and South Africa (1969-2008)

\begin{tabular}{lrrrr}
\hline & \multicolumn{2}{c}{ Kenya } & \multicolumn{2}{c}{ South Africa } \\
\hline Intercept & 6.2648 & 4.5481 & 4.6764 & 4.0024 \\
& $(8.59)$ & $(5.95)$ & $(5.79)$ & $(5.08)$ \\
$\mathrm{Ln}(\mathrm{K} / \mathrm{L})$ & 0.2007 & 0.2747 & 0.499 & 0.3808 \\
& $(2.18)$ & $(3.56)$ & $(6.37)$ & $(5.47)$ \\
$\mathrm{Ln}(\mathrm{H} / \mathrm{L})$ & & 0.1842 & & 0.2193 \\
$\mathrm{R}^{2}$ & & $(3.68)$ & & $(2.21)$ \\
$\mathrm{n}$ & 0.6032 & 0.7123 & 0.9539 & 0.9576 \\
& 39 & 39 & 46 & 46 \\
\hline
\end{tabular}

T-statistics in parentheses. AR2 maximum likelihood method. Ln(K/L): Natural Log of Physical Capital per Employed Worker. Ln(H/L): Natural Log of Human Capital per Employed Worker. Dependent variable: Ln (Y/L): Natural log of real output per employed worker (Productivity).

Table 2 is a summary of our estimate of equation (5). The coefficients indicate that productivity or output per employed worker increases with physical capital per employed worker and human capital per employed worker. Both coefficients are significant at 1 percent level of significance for both Kenya and South Africa.

The estimates in Table 2, suggest that accumulation of physical capital plays a major role in labor productivity in both Kenya and South Africa. The coefficients in tables $(1 \& 2)$ indicate that the contributions of human capital to GDP and to productivity of labor are smaller than the contribution of physical capital. Output and labor productivity growth rates are both constrained by shortage of physical capital. As predicted by Solow's growth theory, the growth rate of output and output per employed worker is higher in low income countries where capital per worker ratio is less than in high countries. The contribution of human capital to growth rates of output and productivity of labor are constrained by insufficiency of physical capital.

If we replicate Weil's method of calculating the return to human capital (Weil, 2013) by multiplying Kenya's human capital share of wages (0.49) by its total wage to GDP ratio of 0.37 from Table 1 , we obtain a human capital share of GDP of only $0.18(0.49 \times 0.37)$ which is significantly less than the 0.33 GDP share of human capital implied by Weil. For South Africa the share of human capital at $0.27(0.49 \times 0.54)$ is higher than for Kenya. Such a low share of GDP for human capital for Kenya could be due to high unemployment and underemployment of workers or due to a low ratio of physical capital per employed worker. 


\subsection{Growth Rates of Factors of Production and Their Contribution to Economic Growth in 31 SSA Countries}

Table 3. Growth rates (in percent) for real output, number of workers, physical capital, human capital and unskilled labor for 31 SSA countries for the period $1975-2008(n=1034)$

\begin{tabular}{lccccc}
\hline \multicolumn{1}{c}{ Country } & Real Output & All Labor & Physical Capital & Unskilled Labor & Human Capital \\
\hline Botswana & 8.50 & 3.93 & 9.01 & 1.33 & 6.30 \\
Mauritius & 5.38 & 1.99 & 5.21 & 1.10 & 2.53 \\
Gambia & 5.27 & 3.21 & 7.62 & 1.82 & 6.62 \\
Mali & 5.02 & 2.12 & 4.50 & 1.24 & 5.97 \\
Rwanda & 4.94 & 2.99 & 5.92 & 1.88 & 5.32 \\
Tanzania & 4.63 & 2.81 & 4.82 & 1.71 & 4.43 \\
Uganda & 4.53 & 3.02 & 5.00 & 1.78 & 4.81 \\
Swaziland & 4.50 & 3.53 & 2.44 & 2.35 & 4.30 \\
Mozambique & 3.74 & 2.08 & 4.68 & 1.69 & 3.28 \\
Congo & & & & & \\
Republic & 3.65 & 3.10 & 5.43 & 2.02 & 4.15 \\
Cameroon & 3.64 & 2.82 & 3.79 & 1.32 & 4.48 \\
Benin & 3.64 & 3.18 & 3.60 & 1.54 & 6.45 \\
Lesotho & 3.58 & 1.65 & 7.47 & 0.45 & 2.90 \\
Kenya & 3.52 & 3.57 & 3.26 & 1.95 & 5.28 \\
Senegal & 3.46 & 2.71 & 5.57 & 1.62 & 3.99 \\
Ghana & 3.36 & 3.09 & 1.64 & 2.02 & 3.89 \\
Mauritania & 3.17 & 2.69 & 3.29 & 1.50 & 4.44 \\
Burundi & 3.12 & 3.06 & 4.82 & 2.07 & 5.39 \\
South Africa & 3.09 & 3.01 & 2.46 & 1.78 & 3.78 \\
Cote d'Ivoire & 2.98 & 3.48 & 1.42 & 2.20 & 5.35 \\
Namibia & 2.89 & 3.05 & 2.73 & 2.55 & 3.46 \\
Zambia & 2.86 & 2.91 & 1.45 & 1.43 & 4.38 \\
Niger & 2.84 & 2.84 & 2.58 & 2.09 & 6.01 \\
Malawi & 2.69 & 2.74 & 0.65 & 1.78 & 4.27 \\
Gabon & 2.28 & 2.71 & 3.86 & 0.64 & 4.47 \\
Togo & 1.73 & 3.59 & 0.95 & 1.79 & 6.03 \\
Sierra Leone & 1.41 & 1.36 & 4.98 & 0.28 & 3.82 \\
Liberia & 1.30 & 2.40 & -5.68 & 0.73 & 4.04 \\
Central African & & & & & \\
Republic & 1.20 & 2.44 & -0.06 & 1.17 & 5.03 \\
Congo & & & & & \\
Republic & -0.44 & 2.87 & 0.26 & 1.68 & 5.01 \\
Zimbabwe & -0.92 & 1.98 & 0.58 & 0.77 & 2.88 \\
Overall & & & & & \\
Average & 3.28 & 2.80 & 3.46 & 1.56 & 4.62 \\
\hline
\end{tabular}

Note: For Liberia and Swaziland the data is for the period 1985 to 2008.

Table 3 shows growth rates of GDP, number of employed workers, stock of physical capital, human capital, and raw-labor for each of 31 SSA countries for the period 1975-2008. Countries are arranged by growth rate of GDP in descending order with Botswana as the highest average growth country with an annual growth rate of 8.50 percent and Zimbabwe with the lowest average growth rate of negative 0.92 percent. Overall, for all countries in the sample real GDP has increased at an annual average annual rate of 3.28 percent, with Botswana, Mauritius and Gambia recording the highest rate and Zimbabwe, Democratic Republic of Congo and others with prolonged civil war and ethnic conflict recording the lowest growth rates.

Among the specific factor inputs that recorded the highest growth rates are human capital with a yearly average growth rate of 4.62 percent followed by growth of the stock of physical capital of 3.46 percent and raw labor 1.56 percent. Although human capital has increased at a rapid rate, its contribution to growth rate of real GDP is very low (0.15) in Kenya and (0.22) in South Africa (Table 1). As pointed earlier, this is due to a high rate of unemployment and/or underemployment of the educated workforce and due to limited availability of physical capital to complement the productivity of raw labor and human capital. Our measurement of human capital is not 
adjusted for changes in the quality of education which is likely to have deteriorated over the years due to a rise in student to teacher ratio and low salary of teachers that can adversely affect teachers' morale and incentive. A casual observation of the data on growth rate of the variables appears to be suggestive of the existence of a positive correlation between growth rates of real GDP and growth rate of human capital. As suggested by endogenous growth theory, it is possible, that growth rate of human capital and real GDP are simultaneously determined.

Table 4. Average growth rates (in percent) for real output, number of employed workers, physical capital, human capital, and unskilled labor for 31 ssa countries

\begin{tabular}{cccccc}
\hline Sub-Periods & $\begin{array}{c}\text { Real } \\
\text { Output }\end{array}$ & All Labor & $\begin{array}{c}\text { Physical } \\
\text { Capital }\end{array}$ & $\begin{array}{c}\text { Unskilled } \\
\text { Labor }\end{array}$ & $\begin{array}{c}\text { Human } \\
\text { Capital }\end{array}$ \\
\hline $1975-1979$ & 3.79 & 2.51 & 6.86 & 1.08 & 5.70 \\
$1980-1984$ & 1.87 & 2.82 & 3.11 & 1.32 & 5.46 \\
$1985-1989$ & 4.04 & 2.96 & 1.49 & 1.45 & 4.96 \\
$1990-1994$ & -0.16 & 2.81 & 1.26 & 1.53 & 4.34 \\
$1995-1999$ & 4.67 & 2.96 & 1.70 & 2.06 & 4.10 \\
$2000-2004$ & 3.81 & 2.85 & 2.88 & 1.85 & 3.99 \\
$2005-2008$ & 5.28 & 2.64 & 8.02 & 1.58 & 3.77 \\
Overall Average & 3.28 & 2.80 & 3.46 & 1.56 & 4.62 \\
\hline
\end{tabular}

Note: For Liberia and Swaziland the data is for the period 1985 to 2008. Divided into five year sub-periods for the period 1975-2008 ( $\mathrm{n}=$ 1034).

Table 4 breaks down the growth into eight 5-year sub-periods and one 4-year sub-period. It shows above average growth rate for most recent 14-year period (1995-2008) despite declining growth rate of all labor, unskilled labor and human capital. However, human capital growth is declining at a slower rate than the other two indicating per capita increase in human capital. It also shows recent spurt in growth of physical capital of 8.02 per cent per year during 2005-2008 period. Perhaps there is some truth behind recent "Africa Rising" stories in Time magazine (Perry, 2012) and other popular media.

Using the estimated coefficients of Table 1 obtained from Kenya's data, which indicate an $\hat{\alpha}$ value (physical capital) of $0.6433, \hat{\beta}$ (human capital) coefficient of 0.1495 and $\hat{\lambda}$ (raw-labor with zero education) coefficient of 0.2210 , we generate an estimate of the Growth Accounting Equation (6) to identify GDP growth accounted by growth rates of physical capital, unskilled labor, human capital, and Total Factor Productivity (TFP) growth. Calculations for South Africa are based on its own estimate of $\hat{\alpha}=0.3979, \hat{\beta}=0.2244$ and $\hat{\lambda}=0.3749$. Table 5 shows estimated contributions of growth of factors of production and TFP to growth rate of real GDP in 31 SSA countries for the period 1975-2008. 
Table 5. Growth rate of real output (in percent) and contributions of growth rates, in percent, of physical capital, human capital, unskilled labor, and total factor productivity by country for 31 SSA countries. period 1975-2008. $(\mathrm{n}=1034)$

\begin{tabular}{|c|c|c|c|c|c|}
\hline \multirow[b]{2}{*}{ Country } & \multirow{2}{*}{$\begin{array}{l}\text { Growth Rate } \\
\text { Real Output }\end{array}$} & \multicolumn{4}{|c|}{ Contributions by Growth Rate of } \\
\hline & & $\begin{array}{c}\text { Physical } \\
\text { Capital }\end{array}$ & $\begin{array}{c}\text { Unskilled } \\
\text { Labor }\end{array}$ & $\begin{array}{l}\text { Human } \\
\text { Capital } \\
\end{array}$ & TFP \\
\hline Botswana & 8.5 & 5.8 & 0.29 & 0.94 & 1.47 \\
\hline Mauritius & 5.38 & 3.35 & 0.24 & 0.38 & 1.4 \\
\hline Gambia & 5.27 & 4.9 & 0.4 & 0.99 & -1.03 \\
\hline Mali & 5.02 & 2.9 & 0.27 & 0.89 & 0.95 \\
\hline Rwanda & 4.94 & 3.81 & 0.41 & 0.8 & -0.07 \\
\hline Tanzania & 4.63 & 3.1 & 0.38 & 0.66 & 0.49 \\
\hline Uganda & 4.53 & 3.21 & 0.39 & 0.72 & 0.2 \\
\hline Swaziland & 4.5 & 1.57 & 0.52 & 0.64 & 1.77 \\
\hline Mozambique & 3.74 & 3.01 & 0.37 & 0.49 & -0.14 \\
\hline Congo Republic & 3.65 & 3.49 & 0.45 & 0.62 & -0.91 \\
\hline Cameroon & 3.64 & 2.44 & 0.29 & 0.67 & 0.24 \\
\hline Benin & 3.64 & 2.32 & 0.34 & 0.96 & 0.02 \\
\hline Lesotho & 3.58 & 4.81 & 0.1 & 0.43 & -1.76 \\
\hline Kenya & 3.52 & 2.1 & 0.43 & 0.79 & 0.2 \\
\hline Senegal & 3.46 & 3.59 & 0.36 & 0.6 & -1.08 \\
\hline Ghana & 3.36 & 1.05 & 0.45 & 0.58 & 1.27 \\
\hline Mauritania & 3.17 & 2.12 & 0.33 & 0.66 & 0.06 \\
\hline Burundi & 3.12 & 3.1 & 0.46 & 0.81 & -1.25 \\
\hline South Africa & 3.09 & 1.22 & 0.34 & 1.2 & 0.33 \\
\hline Cote d'Ivoire & 2.98 & 0.91 & 0.49 & 0.8 & 0.78 \\
\hline Namibia & 2.89 & 1.76 & 0.56 & 0.52 & 0.05 \\
\hline Zambia & 2.86 & 0.93 & 0.32 & 0.65 & 0.96 \\
\hline Niger & 2.84 & 1.66 & 0.46 & 0.9 & -0.18 \\
\hline Malawi & 2.69 & 0.42 & 0.39 & 0.64 & 1.24 \\
\hline Gabon & 2.28 & 2.48 & 0.14 & 0.67 & -1.01 \\
\hline Togo & 1.73 & 0.61 & 0.4 & 0.9 & -0.19 \\
\hline Sierra Leone & 1.41 & 3.2 & 0.06 & 0.57 & -2.43 \\
\hline Liberia & 1.3 & -3.66 & 0.16 & 0.6 & 4.19 \\
\hline $\begin{array}{l}\text { Central African } \\
\text { Republic }\end{array}$ & 1.2 & -0.04 & 0.26 & 0.75 & 0.23 \\
\hline Congo Dem Republic & -0.44 & 0.17 & 0.37 & 0.75 & -1.73 \\
\hline Zimbabwe & -0.92 & 0.37 & 0.17 & 0.43 & -1.9 \\
\hline Overall Average & 3.28 & 2.21 & 0.34 & 0.71 & 0.01 \\
\hline
\end{tabular}

Contributions are calculated as $0.6433\left[\frac{\Delta K}{K}\right], 0.221\left[\frac{\Delta R L}{R L}\right]$ and $0.1495\left[\frac{\Delta H}{H}\right]$ for all countries except for South Africa for which the parameters are $\hat{\alpha}=0.3979, \hat{\beta}=0.2244$ and $\hat{\lambda}=0.3749$.

Table 5 again shows that GDP has increased at an annual average rate of 3.28 percent during the period 1975 2008 for SSA countries. It also shows that about 67 percent (2.21/3.28) of the actual GDP growth is accounted by accumulation of physical capital, 22 percent $(0.71 / 3.28)$ by growth of human capital, 11 percent $(0.34 / 3.28)$ by raw labor and zero percent by TFP. In the countries that recorded growth rate above the average GDP growth rate of 3.28 percent, the growth rate of physical capital and its contribution to GDP growth are also higher, except for Swaziland and Ghana. Swaziland remains to be ruled by a monarchy and relies on wage remittances from South Africa to finance consumption (Central Intelligence Agency, 2012); this is reflected in high growth rate of TFP of 1.77 percent which is supposed to capture country specific exogenous factors. Similarly Ghana's discrepancy is explained by high growth rate of TFP of 1.27 percent, which may have to do with Ghana's better than average governance and stability. In countries that recorded less than the average GDP growth rate of 3.28 percent, growth rate of physical capital accumulation and contribution of capital to GDP growth is also low, except for Burundi. Burundi's anomaly is reflected in negative 1.25 percent growth rate of TFP.

In some war ravaged countries such as Democratic Republic of Congo, Liberia, Zimbabwe and Central African Republic, growth rate of GDP, capital accumulation and contributions of capital to economic growth are either 
close to zero or negative. The decline in capital is most likely caused by destruction of physical infrastructure and by capital outflow. In countries with extended period of civil unrest and conflict such as Zimbabwe, Democratic Republic of Congo, Sierra Leone, Republic of Congo and Burundi growth rate of Solow's residual as measured by TFP is negative possibly due to an adverse supply shocks including drought and war.

Table 6. Average growth rate (in percent) of real output and contributions of growth rate, in percent, of physical capital, human capital, unskilled labor, and total factor productivity for 31 ssa countries divided into five year sub-periods for the period 1975-2008 $(\mathrm{n}=1034)$

\begin{tabular}{lccccc}
\hline Sub-Periods & $\begin{array}{c}\text { Growth } \\
\text { Rate of } \\
\text { Real } \\
\text { Output }\end{array}$ & $\begin{array}{c}\text { Physical } \\
\text { Capital }\end{array}$ & $\begin{array}{c}\text { Unskilled } \\
\text { Labor }\end{array}$ & $\begin{array}{c}\text { Human } \\
\text { Capital }\end{array}$ & TFP \\
\hline $1975-1979$ & 3.79 & 4.39 & 0.24 & 0.87 & -1.71 \\
$1980-1984$ & 1.87 & 1.98 & 0.29 & 0.84 & -1.23 \\
$1985-1989$ & 4.04 & 0.96 & 0.32 & 0.77 & 1.99 \\
$1990-1994$ & -0.16 & 0.82 & 0.34 & 0.68 & -1.99 \\
$1995-1999$ & 4.67 & 1.08 & 0.45 & 0.63 & 2.51 \\
$2000-2004$ & 3.81 & 1.84 & 0.41 & 0.61 & 0.96 \\
$2005-2008$ & 5.28 & 5.12 & 0.35 & 0.58 & -0.77 \\
Overall & 3.28 & 2.21 & 0.34 & 0.71 & 0.01 \\
Average & & & & & \\
\hline
\end{tabular}

Contributions are calculated as $0.6433\left[\frac{\Delta K}{K}\right] 0.221\left[\frac{\Delta R L}{R L}\right]$ and $0.1495\left[\frac{\Delta H}{H}\right]$ for all countries except for South Africa for which the parameters are $\hat{\alpha}=0.3979, \hat{\beta}=0.2244$ and $\hat{\lambda}=0.3749$.

Table 6 breaks down the real output growth, and contribution of physical capital, unskilled labor, human capital and growth rate of TFP into eight 5-year sub-periods and one 4-year sub-period. It shows that above average growth rate for most recent 14-year period (1995-2008) is driven mostly by increasing contribution of physical capital. Decline in contribution to growth of real output by unskilled labor is not surprising. However, decline in contribution of human capital is both surprising and disappointing. So is declining growth rate of TFP which even turned negative over 2005-2008 period. 
5.2 Growth Rate of Productivity and Contribution of Growth Rate of Factors of Productivity per Employed Worker for 31 SSA Countries

Table 7. Growth rates (in percent) of output per employed worker, capital per employed worker and human capital per employed worker and tfp in 31 SSA countries for the period 1975-2008 $(n=1034)$

\begin{tabular}{|c|c|c|c|}
\hline \multirow[b]{2}{*}{ Country } & \multicolumn{3}{|c|}{ Growth Rate of } \\
\hline & Productivity & $\begin{array}{l}\text { Capital-Labor } \\
\text { Ratio }\end{array}$ & $\begin{array}{c}\text { Human Capital-Labor } \\
\text { Ratio }\end{array}$ \\
\hline Botswana & 4.57 & 5.08 & 2.37 \\
\hline Mauritius & 3.39 & 3.22 & 0.54 \\
\hline Mali & 2.9 & 2.39 & 3.85 \\
\hline Gambia & 2.06 & 4.41 & 3.41 \\
\hline Rwanda & 1.95 & 2.92 & 2.33 \\
\hline Lesotho & 1.93 & 5.82 & 1.25 \\
\hline Tanzania & 1.82 & 2.01 & 1.62 \\
\hline Mozambique & 1.66 & 2.6 & 1.2 \\
\hline Uganda & 1.51 & 1.97 & 1.78 \\
\hline Swaziland & 0.97 & -1.09 & 0.78 \\
\hline Cameroon & 0.82 & 0.97 & 1.66 \\
\hline Senegal & 0.75 & 2.86 & 1.28 \\
\hline Congo Republic & 0.55 & 2.33 & 1.05 \\
\hline Mauritania & 0.47 & 0.6 & 1.75 \\
\hline Benin & 0.46 & 0.42 & 3.27 \\
\hline Ghana & 0.27 & -1.45 & 0.8 \\
\hline Sierra Leone & 0.17 & 3.67 & 2.4 \\
\hline South Africa & 0.07 & -0.56 & 0.76 \\
\hline Burundi & 0.05 & 1.76 & 2.33 \\
\hline Niger & 0.01 & -0.25 & 3.18 \\
\hline Zambia & -0.05 & -1.46 & 1.47 \\
\hline Kenya & -0.06 & -0.31 & 1.71 \\
\hline Malawi & -0.06 & -2.1 & 1.53 \\
\hline Namibia & -0.17 & -0.32 & 0.41 \\
\hline Gabon & -0.42 & 1.15 & 1.77 \\
\hline Cote d'Ivoire & -0.5 & -2.06 & 1.87 \\
\hline Liberia & -1.1 & -8.08 & 1.64 \\
\hline $\begin{array}{l}\text { Central } \\
\text { Republic }\end{array}$ & -1.24 & -2.5 & 2.59 \\
\hline Togo & -1.87 & -2.64 & 2.44 \\
\hline Zimbabwe & -2.9 & -1.4 & 0.9 \\
\hline Congo Dem Republic & -3.32 & -2.62 & 2.13 \\
\hline Overall Average & 0.48 & 0.66 & 1.82 \\
\hline
\end{tabular}

Productivity $=\frac{\Delta Y}{Y}-\frac{\Delta L}{L} ;$ Capital-Labor ratio $=\left(\frac{\Delta K}{K}-\frac{\Delta L}{L}\right) ;$ Human Capital-Labor ratio $=\left(\frac{\Delta H}{H}-\frac{\Delta L}{L}\right)$. Where $\mathrm{Y}$ is real GDP PPP in 2005 prices, $\mathrm{K}$ is physical capital stock net of depreciation, $\mathrm{L}$ is labor, and $\mathrm{H}$ is the stock of human capital as described in section 3 above. For Liberia and Swaziland the data is for the period 1985 to 2008.

Table 7 shows growth rate of labor productivity, capital to labor ratio and human capital to labor ratios for 31 SSA countries. It shows average yearly growth rate in productivity per employed worker of 0.48 percent, capital to labor ratio 0.66 percent and human capital to labor ratio of 1.82 percent over 1975-2008 period. The good news is that every country had a positive growth rate of human capital to labor ratio indicating increasing level of educational attainment per capita. However, 11 out of 31 countries had negative growth rate of productivity. Of those 11, all except one had negative growth rate in capital to labor ratio. This indicates that growth rate in productivity is driven more by growth rate in capital to labor ratio than by increasing educational attainment. 
Table 8. Average growth rates, in percent, of output per employed worker, capital per employed worker, and human capital per employed worker for 31 SSA countries divided into five year sub-periods for the period 1975$2008(\mathrm{n}=1034)$

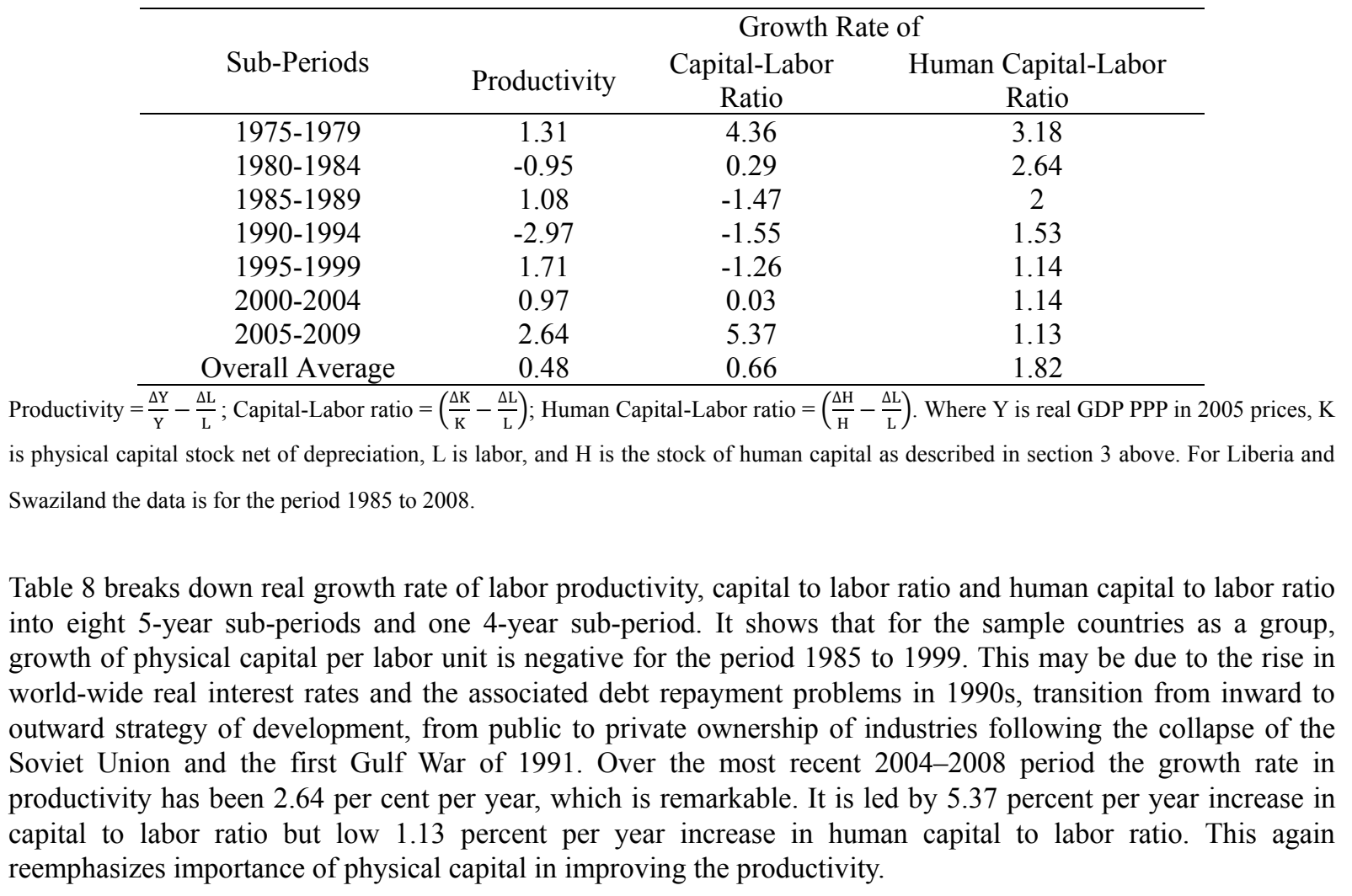


Table 9. Growth rates (in percent) of output-labor ratio and contributions of growth rate, in percent, of capitallabor and human capital-labor ratios and tfp for 31 SSA countries for the period 1975-2008 $(n=1034)$

\begin{tabular}{|c|c|c|c|c|}
\hline \multirow[b]{2}{*}{ Country } & \multirow[b]{2}{*}{$\begin{array}{c}\text { Growth Rate of } \\
\text { Productivity }\end{array}$} & \multicolumn{3}{|c|}{ Contributions of Growth Rate of } \\
\hline & & $\begin{array}{c}\text { Capital-Labor } \\
\text { Ratio }\end{array}$ & $\begin{array}{c}\text { Human } \\
\text { Capital-Labor } \\
\text { Ratio }\end{array}$ & TFP \\
\hline Botswana & 4.57 & 3.30 & 0.28 & 0.98 \\
\hline Mauritius & 3.39 & 2.09 & 0.06 & 1.23 \\
\hline Mali & 2.90 & 1.55 & 0.46 & 0.89 \\
\hline Gambia & 2.06 & 2.87 & 0.41 & -1.22 \\
\hline Rwanda & 1.95 & 1.90 & 0.28 & -0.23 \\
\hline Lesotho & 1.93 & 3.78 & 0.15 & -2.01 \\
\hline Tanzania & 1.82 & 1.31 & 0.19 & 0.32 \\
\hline Mozambique & 1.66 & 1.69 & 0.14 & -0.18 \\
\hline Uganda & 1.51 & 1.28 & 0.21 & 0.01 \\
\hline Swaziland & 0.97 & -0.71 & 0.09 & 1.58 \\
\hline Cameroon & 0.82 & 0.63 & 0.20 & -0.01 \\
\hline Senegal & 0.75 & 1.86 & 0.15 & -1.26 \\
\hline Congo Republic & 0.55 & 1.52 & 0.13 & -1.09 \\
\hline Mauritania & 0.47 & 0.39 & 0.21 & -0.12 \\
\hline Benin & 0.46 & 0.28 & 0.39 & -0.21 \\
\hline Ghana & 0.27 & -0.94 & 0.10 & 1.12 \\
\hline Sierra Leone & 0.17 & 2.38 & 0.29 & -2.50 \\
\hline South Africa & 0.07 & -0.29 & 0.20 & 0.16 \\
\hline Burundi & 0.05 & 1.14 & 0.28 & -1.37 \\
\hline Niger & 0.01 & -0.16 & 0.38 & -0.21 \\
\hline Zambia & -0.05 & -0.95 & 0.18 & 0.73 \\
\hline Kenya & -0.06 & -0.20 & 0.21 & -0.06 \\
\hline Malawi & -0.06 & -1.36 & 0.18 & 1.12 \\
\hline Namibia & -0.17 & -0.21 & 0.05 & -0.01 \\
\hline Gabon & -0.42 & 0.75 & 0.21 & -1.38 \\
\hline Cote d'Ivoire & -0.50 & -1.34 & 0.22 & 0.62 \\
\hline Liberia & -1.10 & -5.26 & 0.20 & 3.96 \\
\hline Central African Republic & -1.24 & -1.63 & 0.31 & 0.08 \\
\hline Togo & -1.87 & -1.71 & 0.29 & -0.44 \\
\hline Zimbabwe & -2.90 & -0.91 & 0.11 & -2.10 \\
\hline Congo Dem Republic & -3.32 & -1.70 & 0.26 & -1.87 \\
\hline Overall Average & 0.48 & 0.43 & 0.22 & -0.17 \\
\hline
\end{tabular}

Table 9 shows the contributions by growth rate of factors of production per unit of labor and TFP to growth rate of productivity in 31 SSA countries for the period 1975-2008. Contributions of growth rates of factors of production per unit of labor and factor-neutral TFP growth are computed using equation (7) above. The Growth Accounting estimates of Table 9 are calculated using estimated coefficient values of $\alpha=0.6433, \beta=0.1495$ for Kenya as reported in Table 1 above. For the group as a whole, productivity of labor has grown at annual average rate of 0.48 percent. Of that 0.43 percent or 90 percent of the total $(0.43 / 0.48)$ is accounted by growth rate of physical capital per labor unit, 0.22 percent or 46 percent of the total $(0.22 / 0.48)$ by growth rate of human capital per labor unit and negative 0.17 percent or negative 36 percent of the total $(-0.17 / 0.48)$ by decline in TFP. Eleven out of 31 countries had negative growth rate of productivity, of those all except one had negative contribution from growth rate in capital to labor ratio. Bosworth and Collins (2003) study for 19 SSA countries finds that 83 percent of the actual productivity growth is accounted by growth of physical capital per worker, 50 percent by growth of human capital per worker and negative 17 percent by declines in TFP. The two results are approximately similar and mutually reinforce each other even though the sample periods and methodological approaches are different. 
Table 10. Average growth rates (in percent) of output-labor ratio and contributions of growth rate, in percent, of capital-labor and human capital-labor ratios and tfp for 31 SSA countries divided into five year sub-periods, for the period $1975-2008(n=1034)$

\begin{tabular}{ccccc}
\hline Sub-Periods & $\begin{array}{c}\text { Growth Rate of } \\
\text { Productivity }\end{array}$ & $\begin{array}{c}\text { Contributions of Growth Rate of } \\
\text { Capital-Labor } \\
\text { Ratio }\end{array}$ & $\begin{array}{c}\text { Human } \\
\text { Capital-Labor } \\
\text { Ratio }\end{array}$ & TFP \\
\hline $1975-1979$ & 1.31 & 2.83 & 0.38 & -1.90 \\
$1980-1984$ & -0.95 & 0.19 & 0.32 & -1.45 \\
$1985-1989$ & 1.08 & -0.94 & 0.25 & 1.77 \\
$1990-1994$ & -2.97 & -0.99 & 0.19 & -2.18 \\
$1995-1999$ & 1.71 & -0.81 & 0.14 & 2.39 \\
$2000-2004$ & 0.97 & 0.02 & 0.14 & 0.81 \\
$2005-2009$ & 2.64 & 3.47 & 0.14 & -0.97 \\
Overall Average & 0.48 & 0.43 & 0.22 & -0.17 \\
\hline
\end{tabular}

For Liberia and Swaziland the data is for the period 1985 to 2008.

Table 10 breaks down real growth rate of labor productivity and contributions by rate of increase in factors of production per unit of labor and TFP to growth rate of productivity, into eight 5-year sub-periods and one 4-year sub-period. It shows that for the sample countries as a group, growth in productivity was negative for 1990-1994 period led by negative growth rate of physical capital per labor unit and negative 2.18 percent growth rate of TFP. It appears that the rise in world-wide real interest rates and the associated debt repayment problems, transition from inward to outward strategy of development, from public to private ownership of industries following the collapse of the Soviet Union and the first Gulf War of 1991 not only negatively affected the growth rate of physical capital per labor unit but also the growth rate of TFP.

Over the most recent 2004-2008 period high 2.64 percent annual growth rate in productivity is led by 3.47 percent, or 131 percent of the total (3.47/2.64), contribution by increase in capital to labor ratio but low 0.14 percent, or 5 percent of the total $(0.14 / 2.64)$, contribution by increase in human capital to labor ratio. Growth rate of TFP made negative 0.97 percent, or negative 36 percent of the total $(-0.97 / 2.64)$, contribution to growth rate in productivity. This is probably attributable to ongoing conflict and even civil wars in many SSA countries. Despite that, strong contribution of growth rate of physical capital per employed worker accounts for a strong growth in productivity. If not for civil wars, conflicts and corruption, productivity in SSA countries could have increased at a rate of 3.61 percent per year during the period 2005-2009. It could have resulted in much improved living standard for citizens of those countries.

\section{Conclusion}

In this study we have demonstrated empirically that the most important driver of economic growth in SSA countries is the physical capital. Growth in physical capital accounts for 67 percent of GDP growth (Tables 5\&6: 2.21/3.28) on the other hand, growth in human capital accounts for only 22 percent of GDP growth (Tables $5 \& 6$ : 0.71/3.28). Also growth of physical capital employed per employed worker accounts for 90 percent of productivity growth (Tables $9 \& 10: 0.43 / 0.48$ ) but growth in human capital per employed worker accounts for only 46 percent of growth in productivity (Tables $9 \& 10: 0.22 / 0.48$ ). Growth in productivity was affected negatively to the tune of 35 percent by a decline of TFP growth $(-0.17 / 0.48)$.

The reason why human capital has higher impact on productivity growth of employed workers than its direct impact on GDP growth rate could be due to external benefits that educated workers bestow upon all workers to enhance the productivity of the latter. In many developing countries educated workers generate spill over benefits by transferring new methods of farming to small scale farmers and by better health services to that segment of population with low literacy rates.

In more recent period (2004-2008) growth rate of productivity has been remarkably high at 2.64 percent per year with contribution of 3.47 percent per year from growth in physical capital employed per unit of labor and only 0.14 percent per year from growth in human capital per unit of labor. However, growth in productivity was negatively affected by a negative growth of (-0.17 percent) in TFP. This appears to be consistent with Mo Ibrahim Index of African Governance recording divergence between material improvements along with political deterioration (Perry, 2012).

For SSA countries to improve labor productivity and GDP growth even more, they have to improve their 
governance structure and legal framework to strengthen the rule of law and diminish corruption. They need to protect private ownership right of property in a consistent and credible manner to encourage the buildup and retention of internally generated physical and financial capital and attract more external capital. They also have to learn to resolve conflicts in a peaceful manner without getting into civil wars. These measures can go a long way towards turning negative 0.17 percent growth rate in TFP to a positive number, leading to even higher increases in productivity. With increases in productivity, a higher living standard will follow. These changes cannot be easily imposed from outside. They have to come from within Africa from people like Bishop Tutu, Sudanese telecom billionaire Mo Ibrahim or Kenyan photographer turned activist Boniface Mwangi (Perry, 2012) among others.

If SSA countries continue with democratization of their governance structure, privatization of public enterprises, liberalization of trade policies and reinvestment of revenues from mineral and oil exports into infrastructural development in a transparent manner, they can attract more foreign direct investment (FDI). Higher FDI can be used not only in extractive industries but also in labor intensive manufacturing, information technology and service sectors that can augment the rate of return of human capital. With increasing FDI investment into labor intensive service and manufacturing sectors, the rate of return to human capital could be as high it is in high income countries.

\section{References}

Abel, A. B., Bernanke, B. S., \& Croushore, D. (2008). Macroeconomics (6th ed.). Boston: Pearson Education, Inc.

Barro, R. J., \& Lee, J. W. (2012). A new data set of educational attainment in the world, 1950-2010. Journal of Development Economics.

Bernanke, B. S., \& Gurkaynak, R. S. (2001). Is Growth Exogenous? Taking Mankiw, Romer, and Weil Seriously. NBER Macroeconomics Annual, 16, 11-57. http://dx.doi.org/10.1162/088933601320224829

Bosworth, B., \& Collins, S. M. (2003). The empirics of growth: An update. Brookings Papers on Economic Activity, 113-206. http://dx.doi.org/10.1353/eca.2004.0002

Caballero, R. J., Farhi, E., \& Gourinchas, P. O. (2008, Fall). Financial crash, commodity prices, and global imbalances. Brookeing papers on economic activity, 1-55.

Calls, S., \& Jolly, D. (2012, September). Euro zone crisis sends stock markets tumbling Wednesday in Greece and Spain. Retrieved from http://www.sott.net

Central Intellegence Agency. (2012). World factbook. Retrieved from https://www.cia.gov/library/publications/the-world-factbook/geos/wz.html\#top

Galor, O., \& Moav, O. (2006). Das human-kapital: A theory of the demise of the class structure. Review of Economic Studies, 73, 85-117. http://dx.doi.org/10.1111/j.1467-937X.2006.00370.x

Hall, R. E., \& Jones, C. I. (1999). Why do some countries produce so much more output per worker than others? The Quarterly Journal of Economics, 114(1), 83-116. http://dx.doi.org/10.1162/003355399555954

Jorgensen, D. W. (1967). The theory of investment behavior. In R. Ferber (Ed.), Determinants of Investment Behavior (pp. 129-188). National Bureau of Economic research.

Lewis, W. A. (1955). The Theory of Economic Growth. London: Allen \& Unwin.

Mankiw, N. G., Rome, D., \& Weil, D. (1992). A contribution to the empirics of economic growth. The Quarterly Journal of Economics, 107(2), 407-437. http://dx.doi.org/10.2307/2118477

Marquetti, A., \& Foley, D. K. (2012). Extended penn world tables v. 4.0-EPWT 4.0. Retrieved from https://sites.google.com/a/newschool.edu/duncan-foley-homepage/home/EPWT

Mincer, J. A. (1974). Schooling and earnings. In J. A. Mincer (Ed.), Schooling, Experince, and Earnings (pp. 4163). New York: Columbia University Press.

Perry, A. (2012, December 3). Africa Rising. Time, 50-52.

Pritchett, L. (2001). Where has all the education gone? World Bank Economic Review, 15(3), 367-391. http://dx.doi.org/10.1093/wber/15.3.367

Psacharopoulos, G. (1994). Returns to investment in education: A global update. World Development, 22(9), 1325-1343. http://dx.doi.org/10.1016/0305-750X(94)90007-8

Solow, R. M. (1956). A Contribution to the theory of economic growth. Quarterly Journal of Economics, 70(1), 
65-94. http://dx.doi.org/10.2307/1884513

Weil, D. N. (2013). Economic Growth (3rd Ed.). Prentice Hall.

Yuan, K. (2005, February). Asymmetric price movements and borrowing constraints: A rational expectations equilibrium model of crises, contagion, and confusion. The Journal of Finance, 60(1), 379-411. http://dx.doi.org/10.1111/j.1540-6261.2005.00733.x

Zelleke, G., \& Sraiheen, A. (2012). Sources of economic growth in 31 sub-sahara African countries for the period 1975-2008: A growth accounting approach. International Journal of Economics and Finance, 4(10), 54-68. http://dx.doi.org/10.5539/ijef.v4n10p54

\section{Notes}

Note 1. Angola, Burkina Faso, Cape Verde, Comoros, Djibouti, Equatorial Guinea, Ethiopia, Madagascar and Nigeria are excluded because educational attainment data is not available for those countries.

Note 2. From equation (1) we have, $\left(\frac{Y_{t}}{Y_{t-1}}\right)=\left[\frac{A_{t}\left(K_{t}{ }^{\alpha} H_{t}{ }^{\beta} L_{t}{ }^{\lambda}\right)}{A_{t-1}\left(K_{t-1}{ }^{\alpha} H_{t-1}{ }^{\beta} L_{t-1}{ }^{\lambda}\right)}\right] \quad$ Or, $\left(\frac{Y_{t}}{Y_{t-1}}\right)=\left[\left(\frac{A_{t}}{A_{t-1}}\right)\left(\frac{K_{t}}{K_{t-1}}\right)^{\alpha}\left(\frac{H_{t}}{H_{t-1}}\right)^{\beta}\left(\frac{L_{t}}{L_{t-1}}\right)^{\lambda}\right]$.

Note 3. From equation (4) we have, $\left(\frac{y_{t}}{y_{t-1}}\right)=\left[\frac{A_{t}\left(k_{t}{ }^{\alpha} h_{t}{ }^{\beta}\right)}{A_{t-1}\left(k_{t-1}{ }^{\alpha} h_{t-1}{ }^{\beta}\right)}\right] \operatorname{Or},\left(\frac{y_{t}}{y_{t-1}}\right)=\left[\left(\frac{A_{t}}{A_{t-1}}\right)\left(\frac{k_{t}}{k_{t-1}}\right)^{\alpha}\left(\frac{h_{t}}{h_{t-1}}\right)^{\beta}\right]$

Taking natural $\log$ of both sides we have, $\operatorname{Ln}\left(\frac{y_{t}}{y_{t-1}}\right)=\operatorname{Ln}\left(\frac{A_{t}}{A_{t-1}}\right)+\alpha \operatorname{Ln}\left(\frac{k_{t}}{k_{t-1}}\right)+\beta \operatorname{Ln}\left(\frac{h_{t}}{h_{t-1}}\right)$.

\section{Copyrights}

Copyright for this article is retained by the author(s), with first publication rights granted to the journal.

This is an open-access article distributed under the terms and conditions of the Creative Commons Attribution license (http://creativecommons.org/licenses/by/3.0/). 